\title{
Culinary alternatives for common beans (Phaseolus vulgaris L.): sensory characteristics of immature seeds
}

\author{
Roser Romero del Castillo, ${ }^{a}$ Juan José Ferreira, ${ }^{b}$ Elena Pérez-Vega, ${ }^{b}$ \\ Antoni Almirall ${ }^{\mathrm{a}}$ and Francesc Casañas ${ }^{\mathrm{a} *}$
}

\begin{abstract}
BACKGROUND: Immature bean seeds feature in several dishes in southern Europe; however, they are not used in all traditional areas of dry beans cultivation. To determine whether differences in the use of immature seeds are due to cultural reasons or intrinsic properties of the seeds, the prestigious varieties of beans cultivated in three areas of Spain with different traditions regarding the use of immature seeds in bean dishes were studied.

RESULTS: We found differences in the culinary and sensory traits between beans harvested when mature and those harvested when immature in the three areas. However, the degree and direction of these differences varied according to the area. Moreover, the different varieties tested within each area responded differently. The sum of the genetic, environmental and interaction effects results in complex alternatives to the mature beans; the gastronomic tradition has taken advantage of only some of these alternatives.

CONCLUSIONS: A lack of traditional dishes using immature beans does not mean that the local beans harvested when immature lack suitable sensory traits. Specific trials in each area of cultivation can reveal alternative textures and bean flavour intensities in immature seeds.
\end{abstract}

(C) 2010 Society of Chemical Industry

Keywords: sensory analysis; gastronomic alternatives; cuisine; bean seeds

\section{INTRODUCTION}

The gastronomic prestige of many foods derives from culinary traditions; however, new creations by trend-setting chefs can enhance the gastronomical prestige of beans and increase the presence of this nutritious food in the diets of developed countries. Innovative chefs explore new ingredients to use in their creations and search the market for products to transform and incorporate into their dishes. ${ }^{1,2}$

The common bean (Phaseolus vulgaris L.) is one of the most popular legumes in the world; it may be grown for its seeds or pods (snap beans). The seeds are usually harvested when completely mature (dry beans); however, in many European regions a small portion of the crop is harvested before complete desiccation (shell beans) when the seeds are developed in the pods, show the varietal characteristics, and begin to dry. These immature seeds are called 'pochas' in Spain, 'haricots à égrainer' in France, and 'fagioli freschi sgranati' in Italy. Nevertheless, shell beans are not eaten in all areas where dry beans are traditionally cultivated.

Shell beans are more expensive to produce than mature beans because they must be harvested and shelled manually; moreover, they must be consumed shortly after harvest or preserved by freezing because their high degree of moisture makes them perishable. However, higher production costs do not completely explain why both mature and immature beans are consumed in some regions but not in others.
In Spain, different dry beans traditionally cultivated in distinct areas enjoy special prestige which has been rewarded with European Community marks. Among them, the local cultivars from Catalonia classified in the market class Ganxet which have been awarded Protected Designation of Origin (PDO 'Mongeta del Ganxet Vallès-Maresme'), the market class Fabada growing in Asturias which has Protected Geographic Indication (PGI 'Faba Asturiana'), and some local cultivars from Catalonia belonging to market class Navy, which are applying for PDO 'Fesols de Santa Pau'. Traditionally, the market class Fabada is often consumed immature, Ganxet is hardly ever consumed immature, and the Navy type named Fesol de Santa Pau is never consumed immature. Differences between the culinary and sensory traits of these beans when harvested in the immature and mature states have not been studied objectively, and the genetic and environmental

\footnotetext{
Correspondence to: Francesc Casañas, Escola Superior d'Agricultura de Barcelona, Campus del Baix Llobregat UPC, Av. Canal Olímpic s/n 08860 Castelldefels, Spain.E-mail:francesc.casanas@upc.edu

a Departament d'Enginyeria Agroalimentària i Biotecnologia, UPC, ESAB, Campus del Baix Llobregat, Avda. Canal Olimpic 15, 08860 Castelldefels, Spain
}

b SERIDA, Carretera de Oviedo s.n. Villaviciosa, 33300 Asturias, Spain 
components of the differences, if they exist, have not been described.

The growth of commercial networks for the distribution of frozen food makes it possible to sell immature beans throughout the year. Thus, it is important to determine whether certain beans are not eaten when immature because their sensory and culinary traits make them unsuitable for this purpose or merely because of historical and/or economic factors.

We studied germplasm used in the three above-mentioned traditional Spanish areas of cultivation to determine the extent to which the degree of maturity at harvest, the cultivar, and the environment, generate sensory or culinary differences that can be exploited gastronomically.

\section{MATERIAL AND METHODS Plant material and location}

We studied six cultivars classified in three market classes (Fig. 1): cultivars 'Andecha' and 'Xana', inbred lines L20 and L81, a local landrace from Catalonia (named Tavella Brisa), and the inbred line T9905 (Hyland Seeds, div. of Thompsons Ltd, Blenheim, Ontario Canada). Cultivars 'Andecha' and 'Xana' were obtained at SERIDA and they have a seed phenotype included in the market class Fabada (white, oblong and very large seed; $100 \mathrm{~g} / 100$ seeds) (Fig. 1). Cultivar 'Andecha' is a bean inbred line with type IV indeterminate growth habit $^{3}$ that was obtained through a recurrent selection programme from the local accession V143. ${ }^{4}$ Cultivar Xana is a bean inbred line with type I determinate growth habit ${ }^{3}$ that was obtained from individual selection from the cross between Andecha and the local accession V203. ${ }^{4}$ Although the seeds of both cultivars are classified in the market class Fabada, they differ in the fin gene, involved in the genetic control of the growth habit. Cultivar Andecha is included in the PGI Faba Asturiana.

The inbred lines L20 and L81 were obtained by the Polytechnic University of Catalonia by means of a recurrent selection programme from local accessions. Their seeds are medium-sized (50 g/100 seeds), flattened, markedly hooked-shaped, and white; they belong to the Ganxet market class ${ }^{5,6}$ (Fig. 1). Both have type IV indeterminate growth habit $^{3}$ and are included in the PDO Mongeta del Ganxet Vallès-Maresme.
The Tavella Brisa landrace and the inbred line T9905 belong to the Navy market class ${ }^{5,7}$ (Fig. 1). These are plants with type III and type I growth habits, respectively, ${ }^{3}$ that produce small $(20 \mathrm{~g} / 100$ seeds), round, white seeds. Tavella Brisa is included in the PDO Fesols de Santa Pau.

We selected different locations to represent the differences in soil or climate within the three areas of cultivation. Trials were carried out in seven locations: two in Asturias (Villaviciosa, $43^{\circ} 29^{\prime} 01^{\prime \prime} \mathrm{N}, 05^{\circ} 26^{\prime} 11^{\prime \prime}$ W; elevation $6.5 \mathrm{~m}$; Argüelles, 43 $26^{\prime} 06^{\prime \prime}$ $\mathrm{N}, 6^{\circ} 03^{\prime} 39^{\prime \prime}$ W, elevation $180 \mathrm{~m}$ ); two in Santa Pau (Santa Pau, $42^{\circ} 08^{\prime} 45^{\prime \prime} \mathrm{N}, 2^{\circ} 34^{\prime} 16^{\prime \prime} \mathrm{E}$, elevation $488 \mathrm{~m}$; La Cot, $42^{\circ} 08^{\prime} 60^{\prime \prime}$ $\mathrm{N}, 2^{\circ} 31^{\prime} 58^{\prime \prime} \mathrm{E}$, elevation $634 \mathrm{~m}$ ); and three in Vallès-Maresme (La Roca, $41^{\circ} 34^{\prime} 40^{\prime \prime} \mathrm{N}, 2^{\circ} 19^{\prime} 02^{\prime \prime}$ E, elevation $108 \mathrm{~m}$; Gallecs, $41^{\circ} 34^{\prime} 14^{\prime \prime}$ $\mathrm{N}, 2^{\circ} 11^{\prime} 42^{\prime \prime} \mathrm{E}$, elevation $125 \mathrm{~m}$; Castellar $41^{\circ} 36^{\prime} 03^{\prime \prime} \mathrm{N}, 2^{\circ} 06^{\prime} 01^{\prime \prime} \mathrm{E}$, elevation $299 \mathrm{~m}$ ).

The PGI Faba Asturiana protects the beans of the market class Fabada grown in Asturias (northern Spain). Asturias has a mean annual rainfall of $1000-1500 \mathrm{~L} \mathrm{~m}^{-2}$ distributed unevenly throughout the year but mainly concentrated in the spring and autumn. Summer temperatures are generally moderate and beans do not require irrigation. The $\mathrm{pH}$ of the soil is neutral-acidic, the proportion of organic material is generally high, and textures vary between loamy clay and loamy sand.

The PDO Mongetes del Ganxet Vallès-Maresme is located in eastern Catalonia (north-east of Spain) and comprises Vallès Occidental, Vallès Oriental and Maresme counties. ${ }^{7}$ The climate is mild-dry Mediterranean with mean annual rainfall of $500-700 \mathrm{~L} \mathrm{~m}^{-2}$ distributed unevenly throughout the year but mainly concentrated in the spring and autumn. Summers are generally dry and beans require irrigation. The soils are derived from sedimentary and metamorphic rocks, and soil texture varies from loamy clay, loamy silt, loamy sand, to loam. The $\mathrm{pH}$ is neutral-alkaline and exchangeable Ca is common in the soil.

The proposed PDO Fesols de Santa Pau is located near the Pyrenees in the north of Catalonia; it comprises only a small part of Garrotxa county characterised by volcanic soil. The general climate is mild Mediterranean with continental components. Mean annual rainfall is $1000 \mathrm{~L} \mathrm{~m}^{-2}$ and summer rainfall is sufficient to enable beans to be cultivated without irrigation. The soil is derived from volcanic rock and is characterised by a high concentration of $\mathrm{K}$

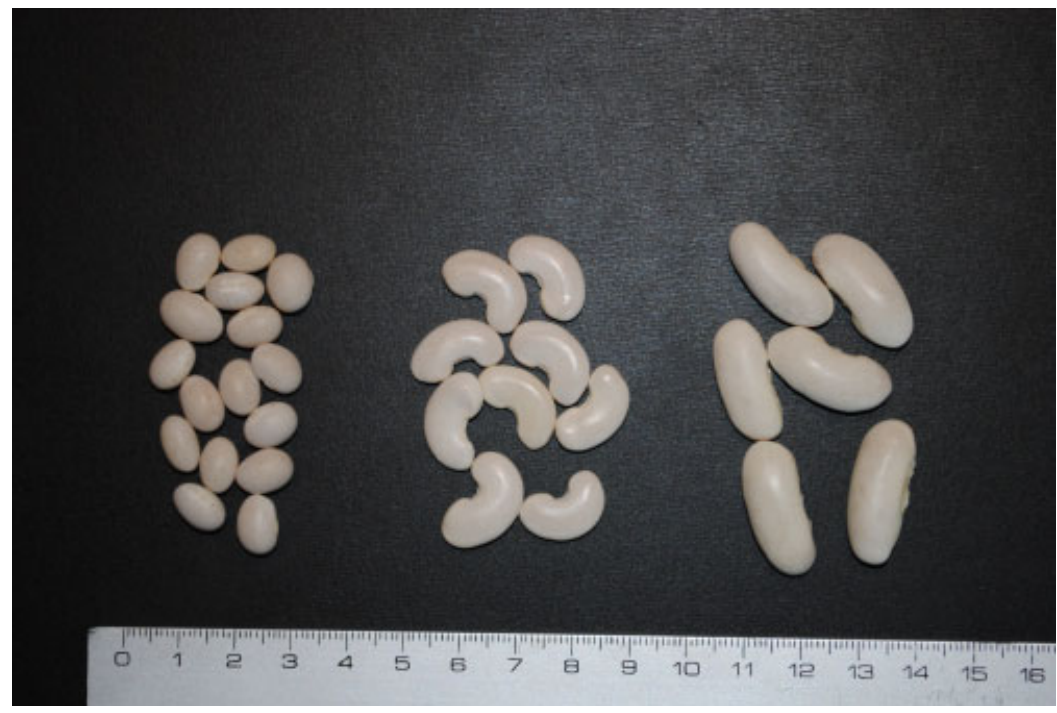

Figure 1. From left to right, Navy, Ganxet and Fabada market classes. Scale in cm. 
Table 1. Main characteristics of the experimental design

\begin{tabular}{|c|c|c|c|c|c|}
\hline \multirow[b]{2}{*}{ Characteristic } & \multicolumn{5}{|c|}{ Area } \\
\hline & \multicolumn{2}{|c|}{ Asturias } & \multicolumn{2}{|c|}{ Vallès } & Santa Pau \\
\hline Type of harvest & \multicolumn{2}{|c|}{ Mature and immature } & \multicolumn{2}{|c|}{ Mature and immature } & Mature and immature \\
\hline Year & \multicolumn{2}{|c|}{2006 and 2007} & \multicolumn{2}{|c|}{2006 and 2007} & 2006 \\
\hline Plants recorded per plot & \multicolumn{2}{|c|}{65} & \multicolumn{2}{|c|}{96} & 124 \\
\hline Location & \multicolumn{2}{|c|}{ Argüelles and Villaviciosa } & \multicolumn{2}{|c|}{ Gallecs and Castellar } & La Cot and Santa Pau \\
\hline Variety & Andecha & Xana & \multicolumn{2}{|c|}{ L20 and L81 } & Tavella Brisa and T9905 \\
\hline Density plants $\left(\mathrm{ha}^{-1}\right)$ & 76000 & 40000 & & & 120000 \\
\hline Irrigation & \multicolumn{2}{|c|}{ None } & Flooding & Drip & None \\
\hline
\end{tabular}

Table 2. Significance of the $F$ test for different main factors and interactions with the type of harvest (immature or mature) in the culinary traits. Data for the three areas of cultivation are presented separately

\begin{tabular}{|c|c|c|c|c|c|c|}
\hline \multirow[b]{2}{*}{ Factor } & \multicolumn{2}{|c|}{ Vallès } & \multicolumn{2}{|c|}{ Asturias } & \multicolumn{2}{|c|}{ Santa Pau } \\
\hline & Cooking time & $\begin{array}{l}\text { \% Whole beans } \\
\text { after cooking }\end{array}$ & Cooking time & $\begin{array}{l}\text { \% Whole beans } \\
\text { after cooking }\end{array}$ & Cooking time & $\begin{array}{l}\text { \% Whole beans } \\
\text { after cooking }\end{array}$ \\
\hline Type of harvest & $<0.0001$ & 0.002 & 0.0004 & 0.014 & $<0.0001$ & $<0.0001$ \\
\hline Variety & 0.605 & 0.002 & 0.005 & 0.003 & 0.010 & $<0.0001$ \\
\hline Year & 0.014 & 0.16 & 0.089 & 0.771 & - & - \\
\hline Location & 0.666 & 0.008 & 0.019 & 0.628 & 0.652 & 0.002 \\
\hline Variety $\times$ type of harvest & 0.843 & 0.739 & 0.030 & 0.0004 & 0.003 & 0.023 \\
\hline Year $\times$ type of harvest & 0.045 & 0.245 & 0.739 & 0.771 & - & - \\
\hline Location $\times$ type of harvest & 0.823 & 0.137 & 0.453 & 0.020 & 0.137 & 0.027 \\
\hline
\end{tabular}

and high cationic exchange capacity. Soil textures vary between loamy clay and loamy sand. The $\mathrm{pH}$ is neutral-acidic.

\section{Experimental design and statistical analysis}

Trials were carried out during two consecutive years (2006-2007) using a complete randomised four-block design in each year and location and following the traditional management in each area. In Santa Pau, beans were cultivated only in the first year because beans harvested when immature disintegrated during cooking, resulting in an unappealing appearance for consumers (Table 1). Immature and dry seeds were harvested at physiological stages R8 and R9, respectively. ${ }^{8}$ In each location, each variety had two plots in each block to allow separate harvesting. The experiment did not study the varieties outside their usual areas because previous trials demonstrated that these materials adapt poorly and are difficult to grow outside their traditional areas of cultivation (Table 1).

The SAS statistical package version $8.1^{9}$ was used to perform the ANOVA. For the culinary traits in each area we considered three fixed factors: location $(\lambda)$, variety $(v)$, and type of harvest $(\theta)$ and three random factors: year $(y)$, block $(b)$, and session $(s)$, with the linear model: $x_{i j k l m n}=\mu+\lambda_{i}+v_{j}+\theta_{k}+y_{l}+b_{m(\lambda y)}+$ $s_{n}+\lambda_{i} v_{j}+\lambda_{i} \theta_{k}+\lambda_{i} y_{l}+v_{j} \theta_{k}+v_{j} y_{l}+\theta_{k} y_{l}+e_{i j k l m n}$. For the sensory traits in each area, the same model was used replacing the fixed effect block $(b)$ within year and location with the fixed effect panelist $(p)$, as the seeds of the four blocks belonging to the same variety, location and year were mixed for the sensory analysis. The interactions of the factor 'panelist' with the other factors were also included in the linear model. Significant differences between means were established using the least significant difference test.

\section{Sample preparation}

Immature bean seeds were taken to the laboratory within $24 \mathrm{~h}$ after harvest and they were blanched at $95^{\circ} \mathrm{C}$ until the peroxidase assay was negative ${ }^{10}$ (5 min approximately) with the aim of destroying enzymes that might modify the sensory characteristics during cold storage. ${ }^{11,12} \mathrm{Next}$, the seeds were frozen in freezer bags at $-20^{\circ} \mathrm{C}$ until the sensory analysis was performed about 90 days later. Mature seeds were stored at $4{ }^{\circ} \mathrm{C}$ until the sensory analyses were carried out together with the immature seeds.

Mature seeds were prepared using the protocol described by Romero del Castillo et al. ${ }^{13}$ A $250 \mathrm{~g}$ sample of dry beans was prepared as follows:

1. The beans were soaked in $750 \mathrm{~mL}$ distilled water for $12-14 \mathrm{~h}$, drained, placed in a thick-bottomed $2 \mathrm{~L}$ stainless steel pot, and covered with cold distilled water $(1 \mathrm{~cm}$ above the level reached by the beans).

2. The pot was brought to the boil and the heat was then lowered to the minimum.

3. The beans were cooked with a lid on (but steam was allowed to escape); during the cooking process, the level of the water was controlled and cold distilled water was added two or three times to compensate for evaporation (but simmering was maintained at all times). The beans were kept covered with water at all times.

4. When the beans were done (this point was determined by the morphology, colour, and texture of each variety), $2.5 \mathrm{~g} \mathrm{NaCl}$ was added.

Using this technique, the cooked beans can be maintained at $80^{\circ} \mathrm{C}$ for up to $2 \mathrm{~h}$ until the test is performed. 


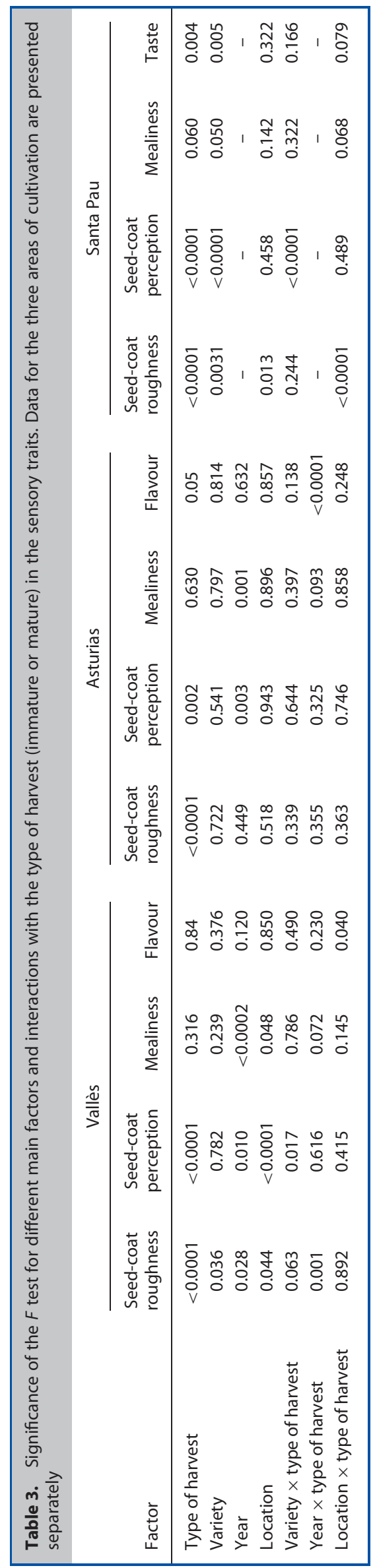


Immature seeds were prepared using a variant of the abovementioned protocol that calls for putting the frozen beans directly in the pot and covering them with cold water. The rest of the procedure was the same as for the preparation of the dry beans.

\section{Sensory analysis}

Samples were submitted to a panel with 12 members who were previously trained over a 2-year period. ${ }^{13}$ All tasting sessions took place in individual booths, meeting the standards set out by the International Organization for Standardization. ${ }^{14}$ The evaluations of each individual sample (variety $\times$ location $\times$ type of harvest $x$ year) were performed in duplicates in sessions where five samples were presented to the 12 panelists.

The intensity of each texture attribute was quantified on a $10 \mathrm{~cm}$ semi-structured scale with the extremes labelled with corresponding descriptions as described by Romero del Castillo et al. ${ }^{13}$ For seed-coat roughness, 0 represented a smooth seed coat like the reference Tolosa bean, and 10 represented a very rough seed coat like the reference Ganxet Montcau bean. For seed-coat perceptibility, 0 stood for extremely low perceptibility, like the Ganxet Montcau bean boiled with distilled water, and 10 stood for very high perceptibility, like the Ganxet Montcau bean boiled in water containing 200 ppm of Ca. For mealiness, 0 meant high creaminess like the Ganxet Montcau bean boiled in distilled water and 10 meant high mealiness like the Tolosa bean cooked in distilled water. For flavour, 0 represented no bean flavour and 10 stood for very intense bean flavour like Tolosa. Montcau is a medium-sized, white, flat and very hooked bean of the Ganxet market class ${ }^{5}$ (Fig. 1) while Tolosa is a middlesized, black and round bean of the Negro Brillante market class. $^{5}$

\section{Culinary traits}

During the preparation of samples for the sensory panel, we recorded the cooking time (time elapsed from when the water breaks a boil until the beans are considered cooked) and percentage of beans that remained whole after cooking for each sample ( $100 \mathrm{~g}$ cooled beans are drained for $5 \mathrm{~min}$; then the whole beans are separated from the broken ones and weighed to calculate the percentage of whole beans). The beans were considered cooked when they were soft enough to be eaten; this was determined by successive sampling made by a trained person.

\section{RESULTS}

\section{Analysis of variance}

The type of harvest factor (dry or immature bean seeds) and the variety factor were significant in the three areas for the two culinary traits evaluated, except in the variety factor for the trait cooking time in the Vallès area (Table 2). The year factor was significant only in the Vallès area for the trait cooking time, whereas the significance of the location factor varied in function of area and trait (Table 2). The two-way interaction that was most frequently significant for the two culinary traits and locations was variety $\times$ maturity at harvest. The significance of the remaining two-way interactions varied in function of area and trait (Table 2).

The type of harvest factor was significant for the sensory traits seed-coat roughness and seed-coat perceptibility in all three areas
(Table 3); this factor was also significant for the trait flavour in the Asturias and Santa Pau areas. No significant differences in mealiness were found between mature and immature beans in any of the areas (Table 3 ).

The variety factor was significant for all sensory traits in Santa Pau but only for seed-coat roughness in Vallès; the variety factor was not significant for any sensory traits in Asturias (Table 3). The year effect was significant for all sensory traits assessed (seed-coat roughness, seed-coat perceptibility, and mealiness) in Vallès and for seed-coat perceptibility and mealiness in Asturias.

The location factor was significant for the sensory traits seedcoat roughness, seed-coat perceptibility, and mealiness in Vallès and for seed-coat roughness in Santa Pau (Table 3). Few two-way interactions were significant and the only interaction that was significant in more than one instance was variety $\times$ maturity at harvest for the trait seed-coat perceptibility in Vallès and in Santa Pau (Table 3).

The analysis of variance indicates that the importance of the main factors and interactions differs between areas, especially for the sensory traits (Tables 2 and 3 ).

\section{Culinary traits}

In the three areas studied, the type of harvest factor had a significant effect on the cooking time and the percentages of whole seeds after cooking, except for percentage of whole seeds after cooking in Santa Pau. Mature bean seeds had a significantly longer cooking time (from $44 \%$ to $53 \%$ ) than immature bean seeds (Table 4). The percentage of whole seeds after cooking was $24 \%$ to $42 \%$ higher in mature seeds than in immature seeds (Table 4). Less than $15 \%$ of whole seeds on a plate (Table 4) would be considered unacceptable (the appearance of seed coats and cotyledons that have been separated is unappealing), so the study was discontinued after the first year in the Santa Pau area.

The differences in cooking time among varieties were very large (Table 4), ranging from $41 \mathrm{~min}$ for the cultivar Tavella Brisa to 100 min for the cultivar Xana. Conversely, the differences in the cooking times between the varieties cultivated in the same region were small, as would be expected because these materials belong to the same market class (Table 4).

When the seeds were harvested in the mature stage, the cultivars included in the types Ganxet and Fabada yielded the highest percentage of whole seeds after cooking (approximately $50 \%$ completely whole beans), whereas the Navy-type cultivated in Santa Pau yielded a much lower percentage (25\%; Table 4). These differences were even greater when the beans were harvested immature: in the market classes Ganxet and Fabada the percentage of unbroken beans descended to $40 \%$, but in the Navy-type beans grown in Santa Pau the percentage of unbroken beans descended to $14 \%$ (Table 4), resulting in, as mentioned, an unappealing appearance for consumers. Furthermore, the separation of the seed coat and cotyledon makes the seed coats more perceptible.

The location effect within area on the cooking time trait was significant only in Asturias, where the beans cultivated in Argüelles needed 33\% longer to cook than those cultivated in Villaviciosa (Table 4).

The percentage of whole beans after cooking was significantly lower in beans cultivated in the location Castellar del Vallès than in those cultivated in the locations La Roca and Gallecs (Table 4). In the Santa Pau area, the percentage of whole beans after cooking 
Table 4. Comparison of the means of each of the main effects for the culinary and sensory traits in each area

Trait

\begin{tabular}{|c|c|c|c|c|c|c|c|c|}
\hline & & & & & & & & \\
\hline Area & Factor & Level & $\begin{array}{l}\text { Cooking } \\
\text { time (min) }\end{array}$ & $\begin{array}{c}\% \text { Whole } \\
\text { beans } \\
\text { after cooking }\end{array}$ & $\begin{array}{l}\text { Seed-coat } \\
\text { roughness }\end{array}$ & $\begin{array}{l}\text { Seed-coat } \\
\text { perception }\end{array}$ & Mealiness & Flavour \\
\hline Asturias & Type of harvest & Immature & $58 \pm 4^{\mathrm{b} *}$ & $40 \pm 4^{b}$ & $5.94 \pm 0.18^{\mathrm{a}}$ & $3.28 \pm 0.17^{b}$ & $4.65 \pm 0.17^{a}$ & $4.79 \pm 0.16^{\mathrm{a}}$ \\
\hline & & Mature & $104 \pm 8^{\mathrm{a}}$ & $52 \pm 5^{a}$ & $3.52 \pm 0.12^{b}$ & $4.13 \pm 0.13^{a}$ & $4.76 \pm 0.13^{a}$ & $4.32 \pm 0.11^{b}$ \\
\hline & Variety & Xana (Faba) & $100 \pm 11^{\mathrm{a}}$ & $39 \pm 3^{b}$ & $4.73 \pm 0.17^{a}$ & $3.64 \pm 0.15^{\mathrm{a}}$ & $4.74 \pm 0.16^{\mathrm{a}}$ & $4.58 \pm 0.14^{\mathrm{a}}$ \\
\hline & & Andecha (Faba) & $70 \pm 5^{b}$ & $54 \pm 5^{a}$ & $4.64 \pm 0.18^{b}$ & $3.81 \pm 0.16^{\mathrm{a}}$ & $4.67 \pm 0.15^{b}$ & $4.51 \pm 0.14^{\mathrm{a}}$ \\
\hline & Location & Villaviciosa & $74 \pm 8^{b}$ & $46 \pm 4^{\mathrm{a}}$ & $4.70 \pm 0.14^{\mathrm{a}}$ & $3.88 \pm 0.13^{\mathrm{a}}$ & $4.53 \pm 0.13^{b}$ & $4.55 \pm 0.12^{\mathrm{a}}$ \\
\hline & & Argüelles & $98 \pm 9^{a}$ & $48 \pm 6^{a}$ & $4.65 \pm 0.21^{b}$ & $3.40 \pm 0.18^{\mathrm{a}}$ & $5.06 \pm 0.18^{\mathrm{a}}$ & $4.53 \pm 0.15^{\mathrm{a}}$ \\
\hline & Year & 2006 & $77 \pm 7^{\mathrm{a}}$ & $50 \pm 5^{\mathrm{a}}$ & $4.55 \pm 0.17^{a}$ & $4.26 \pm 0.16^{\mathrm{a}}$ & $4.09 \pm 0.15^{b}$ & $4.63 \pm 0.15^{\mathrm{a}}$ \\
\hline & & 2007 & $90 \pm 6^{\mathrm{a}}$ & $45 \pm 4^{\mathrm{a}}$ & $4.76 \pm 0.15^{\mathrm{a}}$ & $3.43 \pm 0.14^{b}$ & $5.04 \pm 0.14^{\mathrm{a}}$ & $4.49 \pm 0.12^{\mathrm{a}}$ \\
\hline Vallès & Type of harvest & Immature & $39 \pm 2^{\mathrm{a}}$ & $44 \pm 3^{b}$ & $6.44 \pm 0.12^{\mathrm{a}}$ & $3.51 \pm 0.12^{\mathrm{a}}$ & $2.89 \pm 0.11^{a}$ & $3.74 \pm 0.11^{\mathrm{a}}$ \\
\hline & & Mature & $82 \pm 4^{b}$ & $58 \pm 3^{a}$ & $4.45 \pm 0.14^{b}$ & $2.69 \pm 0.11^{b}$ & $3.07 \pm 0.12^{\mathrm{a}}$ & $3.82 \pm 0.11^{\mathrm{a}}$ \\
\hline & Variety & L20 (Ganxet) & $62 \pm 5^{\mathrm{a}}$ & $45 \pm 2^{b}$ & $5.69 \pm 0.13^{\mathrm{a}}$ & $3.09 \pm 0.11^{b}$ & $2.86 \pm 0.11^{\mathrm{a}}$ & $3.95 \pm 0.11^{\mathrm{a}}$ \\
\hline & & L81 (Ganxet) & $57 \pm 6^{a}$ & $57 \pm 3^{a}$ & $5.23 \pm 0.14^{b}$ & $3.14 \pm 0.12^{\mathrm{a}}$ & $3.09 \pm 0.12^{\mathrm{a}}$ & $3.61 \pm 0.11^{\mathrm{a}}$ \\
\hline & Location & La Roca & $59 \pm 6^{a}$ & $53 \pm 3^{a}$ & $5.76 \pm 0.17^{a}$ & $2.63 \pm 0.14^{b}$ & $2.68 \pm 0.14^{b}$ & $3.45 \pm 0.15^{\mathrm{a}}$ \\
\hline & & Gallecs & $64 \pm 7^{\mathrm{a}}$ & $57 \pm 4^{a}$ & $5.61 \pm 0.17^{a}$ & $4.16 \pm 0.14^{\mathrm{a}}$ & $3.18 \pm 0.13^{a}$ & $3.67 \pm 0.13^{a}$ \\
\hline & & Castellar & $59 \pm 7^{a}$ & $42 \pm 5^{b}$ & $5.04 \pm 0.17^{b}$ & $2.43 \pm 0.13^{b}$ & $3.06 \pm 0.14^{\mathrm{a}}$ & $3.56 \pm 0.14^{\mathrm{a}}$ \\
\hline & Year & 2006 & $68 \pm 6^{a}$ & $54 \pm 3^{a}$ & $5.12 \pm 0.16^{\mathrm{a}}$ & $2.84 \pm 0.12^{b}$ & $2.58 \pm 0.11^{b}$ & $3.98 \pm 0.112^{a}$ \\
\hline & & 2007 & $54 \pm 4^{b}$ & $48 \pm 3^{a}$ & $5.77 \pm 0.12^{b}$ & $3.34 \pm 0.11^{\mathrm{a}}$ & $3.31 \pm 0.11^{\mathrm{a}}$ & $3.58 \pm 0.11^{\mathrm{a}}$ \\
\hline Santa Pau & Type of harvest & Immature & $32 \pm 5^{b}$ & $15 \pm 6^{a}$ & $5.38 \pm 0.25^{\mathrm{a}}$ & $5.08 \pm 0.25^{\mathrm{a}}$ & $4.56 \pm 0.22^{\mathrm{a}}$ & $3.48 \pm 0.24^{\mathrm{a}}$ \\
\hline & & Mature & $64 \pm 3^{a}$ & $27 \pm 4^{a}$ & $1.78 \pm 0.15^{b}$ & $4.20 \pm 0.23^{b}$ & $3.86 \pm 0.22^{\mathrm{a}}$ & $4.57 \pm 0.19^{b}$ \\
\hline & Variety & Tav. Brisa (Navy) & $41 \pm 9^{b}$ & $14 \pm 2^{b}$ & $4.03 \pm 0.29^{a}$ & $6.37 \pm 0.22^{\mathrm{a}}$ & $4.62 \pm 0.24^{\mathrm{a}}$ & $3.41 \pm 0.22^{\mathrm{b}}$ \\
\hline & & T9905 (Navy) & $55 \pm 4^{\mathrm{a}}$ & $29 \pm 3^{a}$ & $3.00 \pm 0.25^{b}$ & $3.17 \pm 0.17^{b}$ & $3.85 \pm 0.21^{\mathrm{a}}$ & $4.56 \pm 0.21^{\mathrm{a}}$ \\
\hline & Location & La Cot & $47 \pm 8^{a}$ & $24 \pm 5^{\mathrm{a}}$ & $3.78 \pm 0.32^{\mathrm{a}}$ & $4.72 \pm 0.27^{\mathrm{a}}$ & $4.46 \pm 0.25^{\mathrm{a}}$ & $3.87 \pm 0.23^{\mathrm{a}}$ \\
\hline & & Santa Pau & $49 \pm 7^{a}$ & $19 \pm 3^{b}$ & $3.13 \pm 0.24^{\mathrm{a}}$ & $4.53 \pm 0.24^{b}$ & $3.88 \pm 0.23^{a}$ & $4.22 \pm 0.25^{a}$ \\
\hline
\end{tabular}

* Mean and standard deviation of the mean. Values for the same effect, area, and trait followed by the same letter were not significant at $p \leq 0.05$ in the least significant difference test.

was significantly lower in beans cultivated near the town of Santa Pau than in those cultivated in the location La Cot (Table 4).

The year effect was only significant for the culinary trait cooking time in the Vallés area (Table 4).

\section{Sensory traits}

In all three areas, seeds harvested when immature had a significant rougher seed coat than those harvested in the mature stage (Table 4). This difference was greatest in the Navy-type beans cultivated in Santa Pau (Table 4).

Significant differences were also found in seed-coat perceptibility in the three areas, although these differences were not all in the same direction. Whereas in the areas of the Vallès and Santa Pau immature bean seeds had more perceptible seed coats, in Asturias immature seeds had less perceptible seed coats than mature seeds (Table 4).

Significant differences in the sensory attribute mealiness between immature and mature bean seeds were found only in the Vallès area; however, these differences were small and would be barely perceptible to consumers (Table 4). In Asturias, the intensity of the flavour was significantly greater in the immature beans than in the mature beans (Table 4). In Santa Pau, the intensity of the flavour was greater in the mature beans, and in Vallès there were no significant differences in the intensity of the flavour of mature and immature beans (Table 4).
The variety factor had variable influence on the sensory traits evaluated and the greatest differences were found for seed-coat roughness (Table 4). In the three market classes, significant differences among cultivars were found for this trait.

The results also showed some significant differences in sensory traits between locations within the same protected area: seedcoat roughness and mealiness in Asturias, seed-coat roughness, seed-coat perceptibility and mealiness in Vallès, and seed-coat perceptibility in Vallès (Table 4).

Finally, the factor year showed a variable effect on the four sensory traits evaluated, depending on the location (Table 4). In Asturias, the year was significant for seed-coat perceptibility and mealiness; in Vallès, it was significant for seed-coat roughness, seed-coat perceptibility, and mealiness.

\section{DISCUSSION AND CONCLUSIONS}

In the present study significant differences were found between mature and immature bean seeds in the two culinary traits evaluated and in sensory traits such as roughness and seed-coat perception. Immature bean seeds are not used in all European areas where prestigious varieties of beans are traditionally grown, although some varieties are used in well-established traditional dishes (fabada, fabas con almejas, pote asturiano in Asturias, ${ }^{15}$ 
Table 5. Mean values of the culinary and sensory traits in the two types of harvest (mature and immature) in the three protected areas

\begin{tabular}{llcccccc}
$\begin{array}{l}\text { Type of } \\
\text { harvest }\end{array}$ & Area & Cooking time & $\begin{array}{c}\text { \% Whole seeds } \\
\text { after cooking }\end{array}$ & $\begin{array}{c}\text { Seed-coat } \\
\text { roughness }\end{array}$ & $\begin{array}{c}\text { Seed-coat } \\
\text { perception }\end{array}$ & Mealiness \\
\hline Mature & Asturias & $104 \pm 9^{\mathrm{a} *}$ & $52 \pm 5^{\mathrm{a}}$ & $3.17 \pm 0.13^{\mathrm{d}}$ & $4.16 \pm 0.15^{\mathrm{a}}$ & $4.87 \pm 0.16^{\mathrm{a}}$ & $4.29 \pm 0.16^{\mathrm{b}}$ \\
& Vallès & $82 \pm 4^{\mathrm{a}}$ & $57 \pm 4^{\mathrm{a}}$ & $4.45 \pm 0.13^{\mathrm{c}}$ & $2.68 \pm 0.10^{\mathrm{c}}$ & $3.07 \pm 0.11^{\mathrm{bc}}$ & $3.85 \pm 0.19^{\mathrm{c}}$ \\
& Santa Pau & $64 \pm 3^{\mathrm{b}}$ & $27 \pm 4^{\mathrm{c}}$ & $1.78 \pm 0.16^{\mathrm{e}}$ & $4.21 \pm 0.24^{\mathrm{a}}$ & $3.87 \pm 0.123^{\mathrm{b}}$ & $4.57 \pm 0.27^{\mathrm{b}}$ \\
& & & & & & \\
Immature & Asturias & $59 \pm 5^{\mathrm{b}}$ & $39 \pm 4^{\mathrm{b}}$ & $5.97 \pm 0.20^{\mathrm{ab}}$ & $3.24 \pm 0.15^{\mathrm{b}}$ & $4.67 \pm 0.18^{\mathrm{a}}$ & $4.77 \pm 0.20^{\mathrm{a}}$ \\
& Vallès & $39 \pm 3^{\mathrm{c}}$ & $44 \pm 3^{\mathrm{b}}$ & $6.44 \pm 0.16^{\mathrm{a}}$ & $3.51 \pm 0.12^{\mathrm{b}}$ & $2.89 \pm 0.11^{\mathrm{c}}$ & $3.84 \pm 0.19^{\mathrm{c}}$ \\
& Santa Pau & $33 \pm 5^{\mathrm{c}}$ & $15 \pm 36^{\mathrm{c}}$ & $5.20 \pm 0.25^{\mathrm{b}}$ & $4.54 \pm 0.23^{\mathrm{a}}$ & $4.54 \pm 0.23^{\mathrm{a}}$ & $3.88 \pm 0.22^{\mathrm{c}}$ \\
\hline
\end{tabular}

Values in the same column followed by the same letter were not significantly different at $P \leq 0.05$ in the least significant difference test.

* Mean and standard deviation of the mean.

pasta e fagioli borlotti da sgranare in Italy, haricots rouges frais à la basquaise or potage purée d'haricots frais in France, $^{2}$ etc). Our results indicate that the differences between mature and immature bean seeds are not linear and that these differences depend on both genetic and environmental factors. Of the three areas studied, one, Santa Pau, produced immature beans that did not apparently improve the gastronomic possibilities of the beans: although the immature beans cooked faster than the mature beans, the number of broken beans increased, the roughness and perceptibility of the seed coat also increased, and the intensity of the flavour of the beans, already relatively low in mature beans, decreased (Table 5). Perhaps this is why immature beans do not form part of the traditional cuisine in Santa Pau and have not even been used in new dishes by the most innovative chefs. At the other extreme, using immature beans in Asturias decreases cooking time (long for mature beans), only slightly decreases the percentage of whole beans after cooking, increases the roughness of the seed coat but decreases its perceptibility, slightly decreases the mealiness, and increases the flavour intensity in comparison with mature beans (Table 5). Indeed, these differences seem to have been recognised in the traditional cuisine and by innovative chefs, both of which have created objectively different dishes that are appreciated by consumers. 2,15,16 The third protected area studied, Vallès, probably offers more possibilities for developing new products for consumers. When harvested mature, the beans admitted in this PDO cook quickly and have low seed-coat perceptibility, high creaminess, and mild flavour (Table 5). Perhaps because the mature bean is highly appreciated, the alternatives offered by the immature bean were not so evident for the traditional cuisine as in the case of Faba Asturiana.

The location within area effect, attributable mainly to soil differences, had a variable influence on the traits evaluated. The Vallès area has some variability in soil characteristics and this tends to result in greater sensory differences between locations, although these differences are always small. ${ }^{7}$

Significant differences within the same market class must be attributed to differences in the genotypes used. The greatest differences between cultivars within a market class were found in Santa Pau, probably due to the wide range of genotypes included in this PDO and chosen for the present experiment (all types of beans belonging to the Navy commercial class are admitted, including both Tavella Brisa, which is a landrace of this area, and improved varieties).

In summary, it seems that the traditional cuisine has embraced or rejected the use of immature beans in the extreme cases (Asturias and Santa Pau), where the differences and the benefits of each kind of harvest are clear. However, there is an intermediate zone where the differences between immature and mature beans are not very evident, where the traditional cuisine has not embraced the use of immature beans, but that is worth exploring the use of immature beans for new culinary creations. Freezing the immature beans after blanching enables them to be used outside the harvest season and to be distributed far from the area where they are cultivated. Because the culinary and gastronomical differences between the mature and immature beans depend on the genotype and environment, comparative trials should be carried out in each area to determine the potential value of the different varieties and areas.

\section{ACKNOWLEDGEMENTS}

This study was financed by the INIA, through project RTA 2005-00115-CO2.

\section{REFERENCES}

1 Bocuse $\mathrm{P}$, La cuisine du marché. Flammarion, Paris, pp. 9-10 (1980).

2 Ducasse A, Méditerranées. Cuisine de l'essentiel. Hachette Livre, Paris, pp. 8-35 (1996).

3 Singh SP, A key for identification of different growth habits of Phaseolus vulgaris L. Annu Rep Bean Improv Coop 25:92-94 (1982).

4 Ferreira JJ, Pérez-Vega E and Campa A, Nuevas variedades de judía tipo Faba Granja desarrolladas en el SERIDA: resultados de las evaluaciones morfológicas, agronómicas y de calidad. SERIDA KRK Ediciones, Oviedo, Spain, (2007).

5 Santalla M, de Ron AM and Voysest O, European bean market classes, in Catalogue of Bean Genetic Resources, ed. by Amurrio M, Santalla M and de Ron AM. Fundación Pedro Barrié de la Maza/PHASELIEUFAIR-PL97-3463-MBG-CSIC, Pontevedra, Spain, pp. 79-94 (2001).

6 Sánchez E, Sifres A, Casañas F and Nuez F, Common bean (Phaseolus vulgaris L.) in Catalonia, a Mesoamerican germplasm hot spot to be preserved. J Hort Sci Biotechnol 82:529-534 (2007).

7 Romero del Castillo R, Almirall A, Valero J and Casañas F, Protected designation of origin in beans (Phaseolus vulgaris L.): towards an objective approach based on sensory and agromorphological properties. J Sci Food Agric 88:1954-1962 (2008).

8 Schoonhoven van A and Pastor-Corrales MA, Standard Systems for the Evaluation of Bean Germplasm. CIAT, Cali, Colombia, p. 54 (1987).

9 SAS Institute, SAS Online Doc Version 8 [CD-rom]. SAS Institute Inc. Cary, NC (1999).

10 Cano MP, HernándezX and De Ancos $B$, High pressure and temperature effects on enzyme inactivation in strawberry and orange products. J Food Sci 62:85-88 (1997).

11 Barret D and Theerakulkait C, Quality indicators in blanched, frozen, stored vegetables, Food Technol January: 62-65 (1995). 
12 Simmonne AH, Weaver DB and Cheng-i Wei. Immature soybean seeds as a vegetable or snack food: acceptability by American consumers, Innov Food Sci Emerging Technol 1:289-296 (2001).

13 Romero del Castillo R, Valero J, Casañas F and Costell, E, Training, validation and maintenance of a panel to evaluate the texture of dry beans (Phaseolus vulgaris L.). J Sensory Stud 23:303-319 (2008).
14 ISO 8589, Sensory analysis - General guidance for the design of test rooms. International Organization for Standardization, Geneva (1988).

15 Méndez Riestra E, Saboreando Asturias. Sociedad Regional de Turismo del Principado de Asturias, Oviedo, p. 39 (2003)

16 Jean-Louis Neveu, Le haricot, la mojhéte et le fayot. Geste éditions, La Créche, France, p. 55 (2002). 